\title{
Comparing Canadian and Colombian Approaches to the Duty to Consult Indigenous Communities on International Treaties
}

\section{Dwight Newman ${ }^{\star}$ and Wendy Elizabeth Ortega Pineda ${ }^{\star *}$}

\section{Introduction}

In recent years, the development in Canada of a constitutional duty to consult Indigenous communities has had ramifications on government decision-making that are widespread, far-reaching, and potentially expansive. ${ }^{1}$ The modern duty to consult doctrine developed in a series of cases in 2004-2005, ensuring that governments have a duty to consult proactively with Aboriginal communities whose Aboriginal or treaty rights may be adversely impacted by a particular administrative decision, even in the face of uncertainty about the scope of asserted rights in the absence of a final settlement or court decision. ${ }^{2}$ Case law development on the duty later established that the duty is also triggered in the context of an early, strategic decision that may determine later administrative decisions. ${ }^{3}$ Some have put forth the argument that the duty may be triggered prior to the adoption of legislation; adjudication on that issue is currently making its way forward through the courts. ${ }^{4}$

The Hupacasath First Nation case, recently decided at the Federal Court of Appeal, raised another question, that of whether or not consultation was owed to Aboriginal communities in the context of international treaty negotiations. ${ }^{5}$ Although the federal government has actually engaged in such consultation in some instances so as to avoid infringing Aboriginal and treaty rights, ${ }^{6}$ the case raised the complex question of whether it is constitutionally required to do so in order to comply with the duty to consult doctrine. On the particular facts of the case, the issue concerned the Canada-China foreign investment treaty, ${ }^{7}$ which the Hupacasath First Nation argued was apt to lead to later infringements on Aboriginal rights. Both the Federal Court and the Federal Court of Appeal rejected these arguments. Their rejection has broader implications, but we shall argue that it leaves open the possibility that the negotiation of some international treaties may trigger the constitutional duty to consult, thus opening a complex nexus between constitutional and international law.

We make this argument partly through an examination of the Hupacasath judgment itself, which we explain further in Part II of this article. In Part III, however, we add a further, comparative perspective, highlighting a string of recent Colombian cases that have considered requirements of consultation with Indigenous communities in the context of Colombian entry into international treaties. Although these requirements partly arise from some different legal structures in Colombia, they speak generally to the nature of consultation. These cases show a clear adoption of a view that the negotiation of international treaties may trigger requirements of domestic consultation with Indigenous communities. But, these cases also show that any 
such triggering must be considered carefully in light of the causation of particular impacts on particular communities. In the concluding Part IV, we suggest that such approaches can flesh out parts of the Hupacasath judgment, helping to identify the potential for the negotiation of international treaties to trigger the constitutional duty to consult and the limits on that potential. We also briefly comment on the value of comparative constitutional law that looks to a wider range of states than have often been considered by Canadian courts and scholars, ${ }^{8}$ arguing that in Indigenous rights contexts, subject to a number of important cautions, there are reasons to consider comparative constitutional law from outside common law traditions.

\section{The Hupacasath Case}

The basic argument in the Hupacasath case was that the adoption of a relatively standard foreign investment agreement with China - which provided remedies for investors harmed by breaches of the agreement - would lessen protections for Aboriginal rights. This argument was made partly on the basis that governments that could face damage claims under the treaty would then, in some circumstances, allegedly be incentivized not to protect Aboriginal rights or to fulfill the duty to consult. In making this argument, the Hupacasath relied upon expert evidence from a law professor critical of investor-state agreements. The Federal Court rejected that evidence as lacking impartiality and as unsubstantiated and ultimately held that there were no non-speculative impacts on Aboriginal rights arising from the agreement. ${ }^{9}$

The case ultimately helped to flesh out the requirement that potential impacts on Aboriginal or treaty rights must be non-speculative if they are to trigger the duty to consult. Indeed, the Federal Court of Appeal interpreted the purpose of the duty to consult as being "aimed at preventing a present, real possibility of harm caused by dishonourable conduct that cannot be addressed later." 10 The Court thus specifies that the duty to consult cannot be triggered by action combined with chains of reasoning made up of assumptions, conjectures, or guesses. ${ }^{11}$ Other- wise, there would be an overly aggressive application of the duty to consult that would subject massive amounts of government action to consultation. The Federal Court of Appeal explains that such aggressive application of the duty would undercut one of the duty's major purposive elements, that of a reconciliatory framework that also includes an appropriate level of respect for countervailing Crown interests. ${ }^{12}$

The Federal Court of Appeal envisions that a future application could be brought if there were actions based on the agreement that triggered the duty to consult, such as in the example of certain types of resource development by Chinese investors. ${ }^{13}$ If such a scenario emerged - entirely speculatively - there could be a potentiallycomplex, even conflicting, interaction between constitutional norms that constrained Canadian governmental conduct domestically and international treaty norms that constrained Canadian governmental action internationally. But, that is not unique to this context - many contexts give rise to the potential for clashes between constitutional law requirements and international law requirements.

The point of the Federal Court of Appeal judgment in Hupacasath is that the duty to consult becomes an issue only where government action has the potential to cause harm to Aboriginal or treaty rights. There must be evidence of a causal link, and there are rigorous standards to establish causation. Quick assumptions cannot automatically be made that international treaties will cause breaches of constitutional rights. The mere possibility in some future scenario for such causation does not amount to present causation of a sort pertinent enough to trigger the duty.

That principle, though, does not mean that no international treaties are subject to constitutional consultation requirements. Indeed, Canadian governmental authorities now seem to implicitly acknowledge the need for consultation in some contexts. For example, if there were negotiations on international treaties about migratory birds, such treaties potentially have an obvious impact on Aboriginal and treaty rights. ${ }^{14}$ Thus, Canadian law has begun to pronounce on the application of constitutional consulta- 
tion requirements in the context of international treaty negotiations and has thus far developed a distinction between direct causal impacts and speculative impacts that do not meet a causation standard. Considering this development alongside Colombian law, though, offers some lessons in each direction.

\section{Colombian Case Law on Consultation on International Treaties}

In this section, we illustrate how the Colombian case law of recent years offers a rich set of examples relating to the issue at hand. By way of background, the legal bases for consultation with Indigenous communities in Colombia are slightly different than in the Canadian context, given Canada's focus on a constitutional duty grounded in the honour of the Crown. In Colombia, the consultation requirement is established in the Political Constitution and through the International Labour Organization (ILO) Convention 169 concerning Indigenous and Tribal Peoples, ${ }^{15}$ ratified by Colombia since $1991^{16}$, which becomes part of the constitutional structure of Colombia.

Even though the term "prior consultation" does not appear in the Constitution, article 330 states: "The exploitation of natural resources in indigenous territories shall be without prejudice to the cultural, social and economic integrity of indigenous communities. The decisions taken in respect of such exploitation, the Government shall encourage the participation of representatives of the respective communities." ${ }^{17}$

In terms of ILO Convention 169, which becomes part of the Colombian constitutional structure, Article 7 of that Convention sets out the underlying requirement as follows: "The peoples concerned shall have the right to decide their own priorities for the process of development as it affects their lives, beliefs, institutions and spiritual well-being and the lands they occupy or otherwise use, and to exercise control, to the extent possible, over their own economic, social and cultural development. In addition, they shall participate in the formulation, implementation and evaluation of plans and programmes for national and regional development which may affect them directly."18

These constitutional rules have been litigated in a number of cases on an issue analogous to the Canadian issue of international treaties and the duty to consult. In recent years, the Constitutional Court of Colombia has addressed the unconstitutionality or constitutionality of bills in cases based on issues related to the alleged lack of prior consultation with Indigenous communities in several cases pertaining to international treaties, basing these judgments on the ILO Convention which became part of Colombian constitutional law. For example, in 2009, in judgment C-615/09, ${ }^{19}$ the Constitutional Court declared Bill 1214 of 2008 unconstitutional. This bill would have approved the Agreement for development and basic assistance of Wayuu indigenous peoples from Colombia and Venezuela. The Agreement aimed at "the realization of a set of plans, programs and projects to improve the living conditions of their respective Wayuu indigenous populations." However, due to the direct impact of this legislation on the Wayuu people, the Court stated that "[the government $\backslash$ should have previously consulted with the Wayuu communities before approving the submission of the draft law to the Congress, because they are the direct beneficiaries of the commitments made by the Contracting States." Even though Bill 1214 could have been positive for the Indigenous peoples involved, it nonetheless failed to meet the duty to consult threshold.

In the context of a general trade agreement, however - specifically, one concerning free trade with Canada that arose in a case two years later - the Court declared constitutional Bill 1411 of 2010 along with the Agreement on annual reports on human rights and free trade between the Republic of Colombia and Canada made in Bogota on May 27, 2010. ${ }^{20}$ In this case, it appears that the lack of any direct impact on the Indigenous communities was determinative, as the Court stated that "the standards prescribed therein are provided uniformly for the majority of Colombians which makes sense since its pur- 
pose is not to issue specific regulations relating to ethnic communities."

The next year, in judgment C-196/12, ${ }^{21}$ the majority position of the Corporation (the court of first instance) upheld the constitutionality of Bill 1458 of 2011, through which the Colombian Congress adopted the International Convention of Tropical Timber of 2006. This lower court concluded that the requirement of consultation was not triggered and it was therefore not necessary to be considered as an element of validity for approval of the treaty. On appeal to a court of second instance, the judge did not agree with the previous judgment on the grounds that the Government should conduct consultation with the communities affected by the treaty, especially different Indigenous and Afro-Colombian groups, before proceeding with the law in the Congress. The obligations in the treaty, contracted by the Colombian State in matters of exploitation and marketing of tropical timber, undoubtedly and directly affected the life, cosmogony, and development of these peoples. Therefore, the law approving the treaty did not meet the established norms of prior consultation and was thus unconstitutional: the bill was focused on the exploitation and use of the country's forest resources, which directly affected the natural environment of ethnic communities and therefore constituted a threat to their existence and integrity.

Another judgment in which the Court determined that a bill was constitutional was in judgment C-822/12. ${ }^{22}$ The treaty at issue pertained to scientific research on certain lands that did not directly relate to any ethnic community settled in the country, so that prior consultation was not a prerequisite, given that the Convention does not make specific reference to scientific research or exploration of natural resources in areas of direct significance to Colombian Indigenous communities. The judgment suggested that had Indigenous lands been directly affected, matters would have been different. It thus begins to clarify the distinction between general legislation that affects all citizens and programs that directly affect Indigenous communities, with the latter giving rise to the duty to consult.
In case C-1051/12, ${ }^{23}$ the Colombian Court declared unconstitutional Bill 1518 of 2012 that was intended to approve the International Convention for the Protection of New Varieties of Plants (UPOV). The relevance of this case is about the different perspectives and arguments concerning the consultation. The arguments against a consultation requirement in advance of this treaty were that there is no direct effect on Indigenous communities because the UPOV Convention provides a general framework, as it affects all the inhabitants of Colombia as a national decision. However, it was argued against the Bill that Indigenous peoples and Afrodescendent communities could also be breeders and that intellectual property rights over seeds may affect the identity, autonomy, and livelihoods of Indigenous people, an argument the Court adopted. Therefore, the Court held that these communities have the right to participate in decisions regarding the implementation of intellectual property rights that are directly related to food security, diversity, traditional knowledge, and the cultural survival of indigenous, AfroColombian, and peasant groups.

Finally, in 2013 in the judgment C-622/13, the Court declared constitutional the "Convention on the Status of Stateless Persons," the "Convention on the Reduction of Statelessness," (CRS) and Bill 1588 of 2012, which approves those two conventions and incorporates them into the constitutional structure. The Ministry of Foreign Affairs stated that the CRS "aims to avoid statelessness, guaranteeing the right to nationality, in consideration of the factors of birth, residence, inheritance and pursuant to the principles of equality, non-discrimination, protection of minorities and territorial integrity." 24 The Court considered that the Convention "does not constitute or contain measures that directly affect indigenous communities and Afro-descendants in Colombia and consequently, no prior consultation was becoming mandatory." The effects that could derive from the Conventions against these groups were, the Court held, no different from those that pertained to other inhabitants of Colombia. 


\section{Conclusions}

The possibility that an international treaty could trigger a domestic consultation obligation is a live one. The Canadian Hupacasath case does not foreclose that possibility in Canada. And, even though they arise in a different legal framework, the cumulation of Colombian cases we have referenced show the real possibility of international treaties directly impacting on Indigenous communities. That prospect cannot be avoided in Canada, in the case of treaties that might have more specific impacts on Indigenous communities.

That said, there is an important line to draw between treaties that affect everyone in the country, including Indigenous communities (and therefore do not trigger any consultation requirements), and those that actually have a direct impact on Indigenous communities (that should trigger a domestic consultation requirement). The Canadian case law offers some more precise ways of identifying causal linkages, notably considering whether it is possible to identify a causal link between the treaty and the impact without the aid of speculation. The Colombian cases arguably fit with that rule, but have not articulated it specifically. They may wish to more explicitly incorporate such a rule so as to offer greater clarity in their decision-making processes.

The Colombian cases have tended to focus on if there is any direct impact on Indigenous communities. In that focus, they provide an additional element for the Canadian courts to consider when these issues arise again. In addition to considering issues of causal link, the Canadian courts should consider whether the evidence in the case shows any actual impact on the identity, autonomy, and/or cultural survival of Indigenous communities, these aspects being what Aboriginal and treaty rights are ultimately protecting. In doing so, it becomes further possible to distinguish between general sorts of economic agreements as opposed to those directly implicating Indigenous cultural interests.

In a short commentary of this sort, we lack the space to consider every aspect of the approaches of these different courts. Some of our suggestions of possible mutual learnings may ultimately be challenged, critiqued, or even rejected. We nonetheless put them forward in the hopes that they offer something useful toward each context, but they require further, detailed analysis as to how they fit into each respective framework. Still, whatever someone makes of these more specific suggestions from our article, several broader points stand.

First, there are situations in which Indigenous communities will be able to frame arguments that they are especially affected by particular international treaties that directly implicate their cultural interests, as we see from the Colombian experience.

Second, Canada and Colombia are both wrestling with some parallel issues, thereby showing the value in finding comparative constitutional law in other states from beyond the common law world. There are real possibilities that other Latin American states, or states from elsewhere in the world that deal with the interaction of Indigenous rights and natural resource development, may have lessons or perspectives to offer. Here in Canada, we need not always be reinventing the wheel or forging rules whose effects are unpredictable.

Third, there are reasons for caution. Although two states may appear to be engaged in developing doctrines on highly parallel issues, they are doing so within different historical contexts and legal cultures. So, there may be reasons why rules have different implications even when they look similar. Comparative constitutional law has not always had a reputation for being carried out consistently but has often been seen as being invoked on behalf of particular causes rather than in a principled manner. Our promotion of its extension to broader comparative contexts is subject to caveats, of course. Those pursuing this project further must articulate detailed, principled methodologies that are appropriately sensitive to the different matters at play.

With that caution, though, even this initial comparative piece on the specific topic of the duty to consult and international treaties high- 
lights real potential for valuable comparative work. The complex intersection of constitutional and international law issues that arises in contexts such as those at issue can benefit from analysis from various states. There is room for important comparative work on consultation issues and different comparative law projects beyond those that have traditionally preoccupied Canadian scholars. This initial foray sets the stage for further such work.

\section{Endnotes}

* Professor of Law and Canada Research Chair in Indigenous Rights, University of Saskatchewan; Visiting Fellow, Princeton University (2015-16). I thank SSHRC for longer-term funding on duty to consult issues in recent years and MITACS for financial support that brought my co-author to the University of Saskatchewan as a MITACS Globalink research intern in my programme. I am also grateful to David Percy for our various discussions on consultation in the hallway between our offices during my visit to the University of Alberta in March 2015.

* Law student, Autonomous University of Baja California, Class of 2015; MITACS Globalink Research Intern, summer 2015, University of Saskatchewan - Dwight Newman; Paralegal, Hera Consultores S.C. I want to thank my coauthor for his support and for accepting me in this important and interesting project, and to MITACS Globalink together with the Government of Saskatchewan for giving me this great opportunity to come to Canada and have an excellent personal and professional experience.

1 On the duty to consult generally, see Dwight G. Newman, Revisiting the Duty to Consult Aboriginal Peoples (Saskatoon: Purich, 2014). For discussion of possible expansions in the doctrine, see: Ibid at 22-23, 59-64; Dwight Newman, The Rule and Role of Law: The Duty to Consult, Aboriginal Communities, and the Canadian Resource Sector (Ottawa: Macdonald-Laurier Institute, 2014) [Newman, Revisiting the Duty to Consult].

2 Newman, Revisiting the Duty to Consult, supra note 1 at 16-19; Haida Nation v British Columbia (Minister of Forests), 2004 SCC 73, [2004] 3 SCR 511; Taku River Tlingit First Nation $v$ British Columbia (Project Assessment Director), 2004 SCC 74, [2004] 3 SCR 550; Mikisew Cree First Nation v Canada (Minister of Canadian Heritage), 2005 SCC 69, [2005] 3 SCR 388.

3 Rio Tinto Alcan Inc. v Carrier Sekani Tribal Council, 2010 SCC at para 44, [2010] 2 SCR 650.

4 See notably Courtoreille v Canada, 2014 FC 1244 (the case is currently being appealed).

5 Hupacasath First Nation v Canada, 2015 FCA 4 [Hupacasath Appeal], aff'g 2013 FC 900 [Hupacasath Trial].

6 See some discussion in Stefan Matiation \& Josée Boudreau, "Making a Difference: The Canadian Duty to Consult and Emerging International Norms Respecting Consultation with Indigenous People" in Oonagh E. Fitzgerald, ed, The Globalized Rule of Law: Relationships between International and Domestic Law (Toronto: Irwin Law, 2006) 397.

7 Agreement Between the Government of Canada and the Government of the People's Republic of China for the Promotion and Reciprocal Protection of Investments, Canada and China, 1 September 2012, FIPA (entered into force 1 October 2014).

8 Amongst others on the limited range of states examined in typical comparative law examinations, see Christopher McCrudden, "A Common Law of Human Rights?: Transnational Judicial Conversations on Human Rights" (2000) 20 Oxford J Leg Stud 499 at 517-18, 521-23 (noting factors affecting which states' courts affect which states' courts). Scholars working in the area similarly tend to look to certain states rather than others. For example, in his recent, masterful work of comparative constitutionalism, Robert Leckey has looked to comparative constitutional jurisprudence from Commonwealth states: Robert Leckey, Bills of Rights in the Common Law (Cambridge: Cambridge University Press, 2015).

9 Hupacasath Trial, supra note 5 at para 42 (stating that Professor Gus van Herten's “assertions on key issues were baldly stated and unsubstantiated").

10 Hupacasath Appeal, supra note 5 at para 83.

11 Ibid at para 117.

12 Ibid at paras 119-20.

13 Ibid at para 104.

14 See Matation \& Boudreau, supra note 6.

15 International Labour Organisation, Convention No. 169 concerning Indigenous and Tribal Peoples in Independent Countries, 27 June 1989 (entered into force 5 September 1991) [ILO Convention No. 169].

16 Grupo Internacional de Trabajo sobre Asuntos Indígenas, Países que ratificaron el 169, (2015), online: $\quad<$ http://www.iwgia.org/derechoshumanos/procesos-internacionales/oit/paisesque-ratificaron-el-169>. 
17 Constitution of Colombia, (promulgated 4 July 1991).

18 ILO Convention No. 169, supra note 15.

19 Corteconstitucionalgovco, Sentencia C-615/09, (2009), online: <http://www.corteconstitucional. gov.co/relatoria/2009/C-615-09.htm $>$.

20 Corteconstitucionalgovco, Sentencia C-187/11, (2011), online: <http://www.corteconstitucional. gov.co/RELATORIA/2011/C-187-11.htm >.

21 Corteconstitucionalgovco, Sentencia C-196/12, (2015), online: <http://www.corteconstitucional. gov.co/RELATORIA/2012/C-196-12.htm>.
22 Corteconstitucionalgovco, Sentencia C-822/12, (2015), online: <http://www.corteconstitucional. gov.co/RELATORIA/2012/C-822-12.htm>.

23 Corteconstitucionalgovco, Sentencia C-1051/12, (2012), online: <http://www.corteconstitucional. gov.co/relatoria/2012/C-1051-12.htm>.

24 Corteconstitucionalgovco, Sentencia C-622/13, (2015), online: <http://www.corteconstitucional. gov.co/RELATORIA/2013/C-622-13.htm>. 
